\title{
MOBILITAS SOSIAL MASYARAKAT PASCA PEMBANGUNAN PERUMAHAN KOTA BARU PARAHYANGAN
}

\author{
Toni Kurniawan', Muhammad Fadhil Nurdin ${ }^{2}$, Budi Sutrisno ${ }^{3}$ \\ Program Studi Sosiologi, Fakultas Ilmu Sosial dan Ilmu Politik, Universitas Padjadjaran \\ tonykurniawan72@gmail.com
}

\begin{abstract}
ABSTRAK
Penelitian ini bertujuan untuk menggambarkan mengenai mobilitas sosial yang terjadi pada masyarakat Dusun 3 RW 14 dan 15 Desa Kertajaya Kecamatan Padalarang Kabupaten Bandung Barat pasca pembangunan perumahan Kota Baru Parahyangan. Penelitian ini dilatar belakangi oleh maraknya pembangunan permukiman perumahan di wilayah pedesaan yang bercorak pertanian dan dengan itu mempengaruhi kondisi sosial masyarakat setempat. Metode penelitian yang digunakan adalah deskriptif kualitatif. Penentuan informan menggunakan teknik purposive sampling. Teknik pegumpulan data diantaranya adalah wawancara terstruktur, observasi non partisipan dan studi dokumen. Pengolahan dan analisis data terdiri dari reduksi data, penyajian data dan penarikan kesimpulan. Hasil penelitian menunjukan, mobilitas sosial yang terjadi pada masyarakat Dusun 3 RW 14 dan 15 pasca pembangunan Perumahan Kota Baru Parahyangan adalah mobilitas sosial horizontal, yakni masyarakat melakukan perpindahan dari status pekerjaan mereka pada posisi yang setara. Baik sebelum maupun pasca pembangunan perumahan Kota Baru Parahyangan, status pekerjaan masyarakat sama-sama dikategorikan sebagai buruh. Di mana sebelum pembangunan perumahan Kota Baru Parahyangan, mayoritas masyarakat melakoni pekerjaan sebagai buruh tani. Sedangkan, pasca pembangunan perumahan Kota Baru Parahyangan, mayoritas masyarakat melakoni pekerjaan sebagai buruh bangunan, pekerja taman (petugas kebersihan), dan pembantu rumah tangga di kompleks perumahan Kota Baru Parahyangan. Selain itu, sebagian besar masyarakat juga melakoni pekerjaan sebagai buruh pabrik.
\end{abstract}

Kata kunci: mobilitas sosial, pembangunan perumahan

\begin{abstract}
This research aims to describe the social mobility that goes on the society of Dusun 3 RW 14 and 15 Kertajaya Village, Padalarang District, West Bandung Regency after the construction of Koto Baru Parahyangan housing. This research is motivated by the advance of housing settlement in rural areas that are patterned by agriculture and thus affects to the social circumstance of local community. The research method used is descriptive qualitative. Determination of informants using purposive sampling technique. Data collection techniques include structured interviews, non-participant observation and document studies. Data processing and analysis consists of data reduction, data presentation and conclusion. The results showed that social mobility that goes on to community of Dusun 3 RW 14 and 15 after the construction of the Kota Baru Parahyangan housing was horizontal social mobility, that is the community moved from their employment status to an equal position. Both before and after the construction of Kota Baru Parahyangan housing, the work status of the community was categorized as laborers. Where, before the construction of Kota Baru Parahyangan housing, the majority of local community worked as farm workers. Meanwhile, after the construction of Kota Baru Parahyangan housing, majority of local community worked as construction workers, garden workers (janitors), and housemaids in Kota Baru Parahyangan housing complex. In addition, most people also work as factory workers.
\end{abstract}

Keywords: social mobility, housing development

\footnotetext{
2. Prodi Pasca Sarjana Sosiologi, Fakultas Ilmu Sosial dan Ilmu Politik, Universitas Padjadjaran m.fadhil.nurdin@unpad.ac.id

3. Prodi Sosiologi, Fakultas Ilmu Sosial dan Ilmu Politik, Universitas Padjadjaran budi.sutrisno@unpad.ac.id
} 


\section{PENDAHULUAN}

Maraknya pembangunan permukiman perumahan di daerah-daerah pedesaan yang bercorak pertanian merupakan salah satu dampak dari ketidak mampuan kota dalam menampung penduduknya dalam menyediakan tempat tinggal. Kota Bandung merupakan salah satu kota besar dengan penduduk terpadat di Indonesia. Berdasarkan data Badan Pusat Statistik, jumlah penduduk Kota Bandung tahun 2016 adalah sebanyak 2.490.622 jiwa dengan laju pertumbuhan penduduk pada tahun tersebut sebesar 0,37 persen. Terkonsentrasinya penduduk di kota Bandung tentu tidak terlepas dari daya tarik kota itu sendiri sebagai pusat ekonomi, pendidikan dan kesehatan. Selain itu, kota Bandung juga terkenal dengan objek wisata, kuliner dan juga cuacanya yang sejuk. Terkonsentrasinya penduduk di pusat kota tentu mengakibatkan semakin sempitnya lahan permukiman karena populasi penduduk yang semakin padat.

Penyediaan tempat tinggal di wilayah-wilayah pinggiran kota tentu menjadi solusi yang memungkinkan karena masih memiliki lahan yang cukup luas. Langkah ini merupakan suatu konsekuensi dari ketidak mampuan kota untuk menampung populasi yang ada di dalamnya, sehingga mengakibatkan dampak tersendiri terhadap wilayah-wilayah pinggiran kota. Di mana pembangunan akan diarahkan pada wilayah-wilayah luar kota tersebut sebagai akibat ketidakmampuan kota dalam menampung populasi masyarakatnya untuk menyediakan tempat tinggal. Salah satu bentuk upaya penyediaan tempat tinggal tersebut adalah pembangunan perumahan Kota Baru Parahyangan yang berlokasi di Desa Kertajaya Kecamatan Padalarang Kabupaten Bandung Barat.

Pembangunan perumahan Kota Baru Parahyangan ini tentu menimbulkan berbagai macam dampak bagi masyarakat setempat dan dengan itu diiringi pula oleh perubahan sosial yang terjadi. Dengan adanya perluasan kota ke arah pinggiran kota yang pertama kali akan terjadi adalah pembagian tanah-tanah yang luas dan kemudian tanah-tanah yang dibagi-bagi itu dikumpulkan kembali dengan waktu relatif cepat dan setelah itu tanah-tanah tersebut akan diborong oleh pihak pengembang atau pengusaha untuk membangun perumahan (Wolfe 1967, dikutip dari Evers, 1986: 23-24). Hal inilah yang terjadi pada masyarakat Desa Kertajaya Kecamatan Padalarang Kabupaten Bandung Barat.

Sebelum pembangunan perumahan Kota Baru Parahyangan dilakukan, mayoritas masyarakat Desa Kertajaya melakoni pekerjaan sebagai petani penggarap atau buruh tani dengan mengolah lahan milik orang lain berdasarkan sistem bagi hasil. Umumnya, masyarakat desa tidak memiliki lahan pertanian secara pribadi, hanya mengolah lahan milik orang lain. Pemilik lahan merupakan orang-orang yang berasal dari luar desa, di antaranya berasal dari Bandung, 
Caringin, Ngamprah dan Rancabali. Produk pertanian yang biasanya dikembangkan oleh masyarakat adalah tanaman padi, jarang untuk membudidayakan tanaman lain seperti halnya palawija. Hal ini disebabkan oleh baiknya sistem pengairan atau irigasi lahan-lahan pertanian yang ada di Desa Kertajaya. Baiknya ketersediaan sistem irigasi ini mendorong masyarakat desa untuk memprioritaskan tanaman padi sebagai produk unggulan.

Ketika terjadinya pembangunan perumahan Kota Baru Parahyangan banyak lahan-lahan pertanian yang produktif dengan tanaman padi dialih fungsikan untuk pembangunan perumahan. Alih fungsi lahan ini tentu berdampak langsung terhadap petani karena kehilangan mata pencahariannya. Lahan merupakan komponen vital bagi petani sebagai wadah untuk mengembangkan berbagai macam bentuk produk pertanian. Kehilangan lahan tentu disertai pula oleh kehilangan mata pencaharian bagi para petani. Oleh karena itu, lahan pertanian merupakan sumber utama mata pencaharian penduduk desa.

Kehilangan mata pencaharian yang terjadi tentu menuntut masyarakat untuk melakukan adaptasi dengan mata pencaharian baru pasca pembangunan perumahan Kota Baru Parahyangan sesuai dengan kondisi struktur yang ada dan ketersediaan lapangan pekerjaan tersebut di dalam masyarakat. Secara sosiologis, perubahan mata pencaharian yang terjadi tentu berimplikasi mobilitas sosial masyarakat pada saat pasca pembangunan perumahan Kota Baru Parahyangan. Oleh karena itu, berdasarkan fenomena tersebut peneliti tertarik untuk mengkaji lebih jauh mengenai bagaimana mobilitas sosial masyarakat Desa Kertajaya, khususnya di Dusun 3, RW.14 dan RW.15 pasca pembangunan perumahan Kota Baru Parahyangan.

\section{METODE PENELITIAN}

Penelitian ini menggunakan metode deskriptif dengan pendekatan kualitataif. Penentuan informan penelitian menggunakan teknik purposive sampling. Pada teknik penentuan informan ini, peneliti menentukan sampel berdasarkan pertimbangan-pertimbangan atau klasifikasi tertentu yang dimiliki oleh sampel. Oleh karena itu, sebelum pengumpulan data dilakukan, peneliti telah menentukan kriteria informan penelitian yang sekiranya dianggap mengetahui pokok permasalahan yang terjadi, dengan itu diharapkan dapat mewakili keseluruhan populasi sebagai upaya untuk memeprtahankan keobjektifan data. Kriteria pertama, adalah informan merupakan warga Dusun 3, RW.14 dan RW.15, Desa Kertajaya, Kecamatan Padalarang, Kabupaten Bandung Barat yang tinggal di daerah tersebut sebelum dan pasca pembangunan perumahan Kota Baru Parahyangan. Kriteria kedua, adalah informan merupakan orang yang memiliki kedudukan atau pengaruh terhadap Desa Kertajaya, baik Kepala Desa, Kepala 
Dusun, Ketua Rukun Warga (RW), Ketua Rukun Tetangga (RT), Tokoh Masyarakat, dan pihak-pihak yang perpengaruh lainnya. Berdsarkan kriteria tersebut, maka bakal calon informan penelitian harus memiliki salah satu dari kedua karakteristik tersebut. Pengumpulan data dalam penelitian ini berupa teknik wawancara terstruktur, observasi non partisipan dan studi dokumen. Sedangkan, pengolahan dan analisis data dalam penelitian ini menggunakan model Miles \& Huberman. Analisis data tersebut terdiri dari tiga alur atau siklus kegiatan yang dilakukan secara bersamaan di antaranya adalah reduksi data, penyajian data dan penarikan kesimpulan. Uji keabsahan data yang digunakan dalam penelitian ini di antaranya adalah triangulasi sumber, triangulasi teknik dan bahan referensi.

\section{KERANGKA TEORITIS}

\section{Mobilitas Sosial}

Mobilitas sosial dipandang sebagai suatu gerakan dalam struktur sosial, di mana terdapat suatu pola-pola tertentu yang yang mengatur organisasi suatu kelompok sosial (Young \& Mack, 1959, dikutip dari Basrowi 2005:65). Lebih jelas Horton \& Hunt (1984:36) juga menjelaskan bahwa mobilitas sosial adalah suatu keinginan yang ingin dicapai, baik status atau pengahasilan yang lebih tinggi dari orang tua seseorang. Maka, gagal maupun berhasilnya seseorang dalam mencapai tujuan mereka tersebut itulah yang disebut oleh Horton \& Hunt sebagai mobilitas sosial.

Lipzet \& Zetterberg (t.t.) seperti dikutip dari Wirawan( 2016:12) terdapat beberapa dimensi dalam mobilitas sosial, di antaranya adalah ranking okupasi atau pekerjaan, konsumsi, kelas sosial dan kekuasaan. Para peneliti berpendapat bahwa pekerjaan adalah salah satu faktor yang terpenting dalam membedakan keyakinan, nilai, norma dan kebiasaan. Pekerjaan merupakan salah satu indikator yang bersifat umum dalam stratifikasi sosial termasuk juga mobilitas sosial sebagai suatu bentuk analisis perubahan yang terjadi pada posisi sosial individu di dalam masyarakat, baik secara horizontal maupun vertikal.

Sorokin (1928, dikutip dari Basrowi 2005:65) membedakan mobilitas sosial berdasarkan tipetipe tertentu. Menurut Sorokin terdapat 2 tipe mobilitas sosial, yakni mobilitas sosial horizontal dan mobilitas sosial vertikal. Mobilitas sosial horizontal dipandang sebagai beralihnya individu atau objek-objek sosial lainnya dari suatu kelompok sosial ke kelompok sosial lainnya yang sejajar atau sederajat. Oleh karena itu, dapat diartikan bahwa dalam mobilitas sosial horizontal tidak terjadi perubahan dalam derajat kedudukan seseorang dan atau objek sosial lainnya di dalam masyarakat. Sedangkan mobilitas sosial vertikal dipandang sebagai suatu perpindahan individu atau objek sosial lainnya dari suatu kedudukan sosial ke 
kedudukan yang lain secara tidak sederajat atau kebalikan dari mobilitas sosial horizontal. Mobilitas sosial vertikal juga dibagi menjadi dua bentuk, yakni naik (social climbing) dan turun (social sinking). Mobilitas sosial vertikal naik maupun mobilitas vertikal turun memiliki dua bentuk utama. Pembagiannya adalah sebagai berikut :

1) Mobilitas sosial vertikal naik

a. Masuknya individu-inividu yang pada awalnya memiliki kedudukan rendah kepada kedudukan yang lebih tinggi, di mana kedudukan tersebut telah ada.

b. Pembentukan suatu kelompok baru, yang mana kemudian di tempatkan diderajat atau posisi yang lebih tinggi dari kedudukan individu-individu pembentuk kelompok tersebut.

2) Mobilitas sosial vertikal turun

a. Turunnya kedudukan seseorang ke kedudukan yang lebih rendah derajatnya daripada kedudukan mereka sebelumnya.

b. Turunnya derajat sekelompok orang yang dapat berbentuk suatu disintegrasi dalam suatu kelompok sebagai satu kesatuan.

Mobilitas sosial tidak hanya terbatas pada individu semata, akan tetapi mobilitas sosial juga mungkin terjadi pada kelompok-kelompok sosial di dalam masyarakat. Contohnya suatu kelompok atau golongan minoritas melakukan asimilasi dengan golongan mayoritas sehingga terjadi mebolitas sosial pada golongan minoritas tersebut (Soekanto 2007:220).

\section{Mata Pencaharian}

Mata Pencaharian secara garis besar dapat dikatakan sebagai suatu bentuk usaha atau kegiatan yang dilakukan oleh seseorang atau sekelompok orang yang bertujuan untuk mencukupi kebutuhan hidupnya. Menurut Supriyadi (t.t.) seperti dikutip Hariadi (2017:15) mata pencaharian adalah sebuah pekerjaan yang bersifat pokok, dilakukan oleh manusia dengan memanfaatkan sumber daya yang ada, bertujuan untuk membangun kehidupan yang memuaskan, dalam artian taraf hidup seseorang. Oleh karena itu, diperlukan sebuah regulasi dengan mempertimbangkan faktor-faktor di antaranya adalah mengawasi sumber daya, lembaga, dan hubungan politik.

Selain itu, Susanto (1993, dikutip dari Kemong t.t:4-5) membagi dua bentuk mata pencaharian, yakni mata pencaharian pokok dan mata pencaharian sampingan. Mata pencaharian pokok dapat diartikan sebagai mata pencaharian utama yang dilakukan untuk memenuhi kebutuhan hidup dengan memanfaatkan sumber daya yang ada. Mata pencaharian di luar mata pencaharian pokok diartikan sebagai mata pencaharian sampingan. 
Ellis \& Allison (2004, dikutip dari Hariadi 2017:15) menyatakan " the term livelihood attempts to capture not just what people do in order to make a living, but the resources that provide them with the capability to build a statisfactory living, the risk. factor that they must consider in managing their resources, and the institusional and police context that either helps or hinders them in the persuit of a viable or improving living”. Ellis \& Allison juga mengugkapkan bahwa, terdapat beberapa bentuk sumber daya yang ada pada seseorang atau kelompok orang dalam melakukan suatu kegiatan dalam memenuhi dan mencukupkan kebutuhan hidupnya. Sumber daya tersebut merujuk kepada modal yang dimiliki oleh seseorang atau sekelompok orang. Modal ini adalah sesuatu yang terdapat di dalam lingkungan sosial, ekonomi, dan ekologi manusia. Berbagai bentuk modal tersebut, antara lain :

1) Modal manusia: keahlian, pendidikan, pengetahuan, kesehatan.

2) Modal fisik: investasi barang yang telah diproduksi, infrastruktur dasar (jalan, sanitasi, sekolah, dan lain sebagainya).

3) Modal finansial: uang, tabungan, akses pinjaman, pendapatan.

4) Modal alam: tanah, air, hutan, minyak bumi dan lain sebagainya.

5) Modal sosial: jaringan, asosiasi.

Berdasarkan pemaparan tersebut dapat disimpulkan bahwa, mata pencaharian adalah suatu bentuk kegiatan yang dilakukan oleh seseorang atau sekelompok orang dengan memanfaatkan sumber daya yang ada, baik sumber daya yang dimiliki maupun sumber daya yang telah tersedia di alam guna meningkatkan taraf hidup. Dalam mengelola sumber daya yang ada, diperlukan adanya pertimbangan risiko-risiko yang mungkin akan ditimbulkan. Selain itu, diperlukan adanya regulasi yang mengatur dan pelaksanaan kebijakan yang dapat merugikan maupun menguntungkan. Sejatinya, mata pencaharian dapat dibedakan menjadi dua yaitu mata pencaharian pokok dan mata pencaharian sampingan.

\section{Klasifikasi Pekerjaan}

Watson (2003) dalam bukunya yang berjudul Sociology, Work and Industry menjelaskan klasifikasi atau pembagian kelas pekerjaan yang tersusun secara horizontal dan juga vertikal (hirarkis). Pembagian kelompok kerja yang tersusun berdasarkan diferensiasi horizontal terdiri dari tiga sektor. Ketiga sektor tersebut diantara adalah sebagai berikut :

1. Sektor primer: pertanian dan extractive industries.

2. Sektor sekunder: manufaktur.

3. Sektor tersier: layanan. 
Pengelompokan kelas pekerjaan yang tersusun secara hirarkis diantaranya adalah sebagai berikut :

1. Kelas I : profesional kelas atas, administrator, manajer, dan pebisnis.

2. Kelas II : profesional kelas rendah, administrator dan manajer; teknisi dan supervisor yang lebih tinggi dari karyawan manual.

3. Kelas III : pekerja non-manual rutin, sebagian besar ulama; tenaga penjualan dan pekerja sejenis serta file service workers.

4. Kelas IV : small proprietors; pengrajin mandiri dan pekerja mandiri nonprofesional lainnya.

5. Kelas $\mathrm{V}$ : teknisi kelas bawah dan pengawas pekerja manual.

6. Kelas VI : pekerja upahan manual yang terampil.

7. Kelas VII : pekerja upahan manual yang terampil; pekerja semi dan tidak terampil.

Klasifikasi kelas berdasarkan kelompok pekerjaan yang tersusun secara hirarkis tersebut sebelumnya telah digunakan dalam penelitian tentang mobilitas kelas di Inggris (Goldthorpe dkk, 1980, dikutip dari Watson 2003:175). Kategori yang digunakan dalam pengklasifikasikan pekerjaan secara hirarkis ini dilihat dari fungsi dan status pekerjaan tersebut di dalam masyarakat.

Badan Pusat Statistik (BPS) juga mengklasifikasikan kelompok pekerjaan yang tersusun secara hirarkis, membagi kelompok pekerjaan kedalam beberapa kelas atau golongan pokok. Pembahasan ini diuraikan oleh BPS dalam publikasi yang berjudul Klasifikasi Jenis Pekerjaan Indonesia (2002). Golongan pokok pekerjaan yang dimaksud di antaranya adalah sebagai berikut :

0. Anggota Tentara Nasional Indonesia (TNI) dan kepolisian negara republik Indonesia.

1. Pejabat legislatif, pejabat tinggi, dan manajer.

2. Tenaga profesional.

3. Teknisi dan asisten tenaga profesional.

4. Tenaga tata usaha.

5. Tenaga usaha jasa dan tenaga usaha penjualan di toko dan pasar.

6. Tenaga usaha pertanian dan peternakan.

7. Tenaga pegolahan dan kerajinan yang berhubungan dengan itu.

8. Operator dan perakit mesin.

9. Pekerja kasar, tenaga kebersihan, dan tenaga yang berhubungan dengan itu. 


\section{PEMBAHASAN}

\section{Proses Pembangunan Perumahan Kota Baru Parahyangan}

Kota Baru Parahyangan dikembangkan oleh perusahaan yang bergerak di bidang properti, perusahaan tersebut yakni PT. Lyman Group. Kota Baru Parahyangan merupakan Kota satelit yang mengedepankan kota mandiri dan berwawasan pendidikan. Kota Baru Parahyangan berdasarkan masterplan, memiliki luas kurang lebih 1.250 Ha. Kota Baru Parahyangan berada pada ketinggian 650-900 meter di atas permukaan laut (Wirawan 2016:54). Area Kota Baru Parahyangan di Kabupaten Bandung Barat tidak hanya mencakup Desa Kertajaya saja, akan tetapi mencakup beberapa desa, di antaranya adalah Desa Bojong Haleuang dan Cikande.

Pembangunan Kota Baru Parahyangan dimulai semenjak tahun 90-an. Berdasarkan penuturan informan yang peneliti wawancarai pembangunan Kota Baru parahyangan dimulai pada tahun 1996. Pembangunan tersebut sempat terhenti akibat krisis ekonomi yang terjadi antara tahun 1997-1998. Pembangunan Kota Baru Parahyangan dilakukan secara bertahap, di mana pada awalnya pembangunan tersebut dimulai dengan pembangunan jalan raya. Walaupun demikian, menurut salah satu informan, pembangunan perumahan dan beberapa fasilitas lainnya di area Kota Baru Parahyangan baru dimulai semenjak tahun 2008. Sampai saat sekarang pembangunan berbagai macam fasilitas di area Kota Baru Parahyangan masih tetap berlangsung.

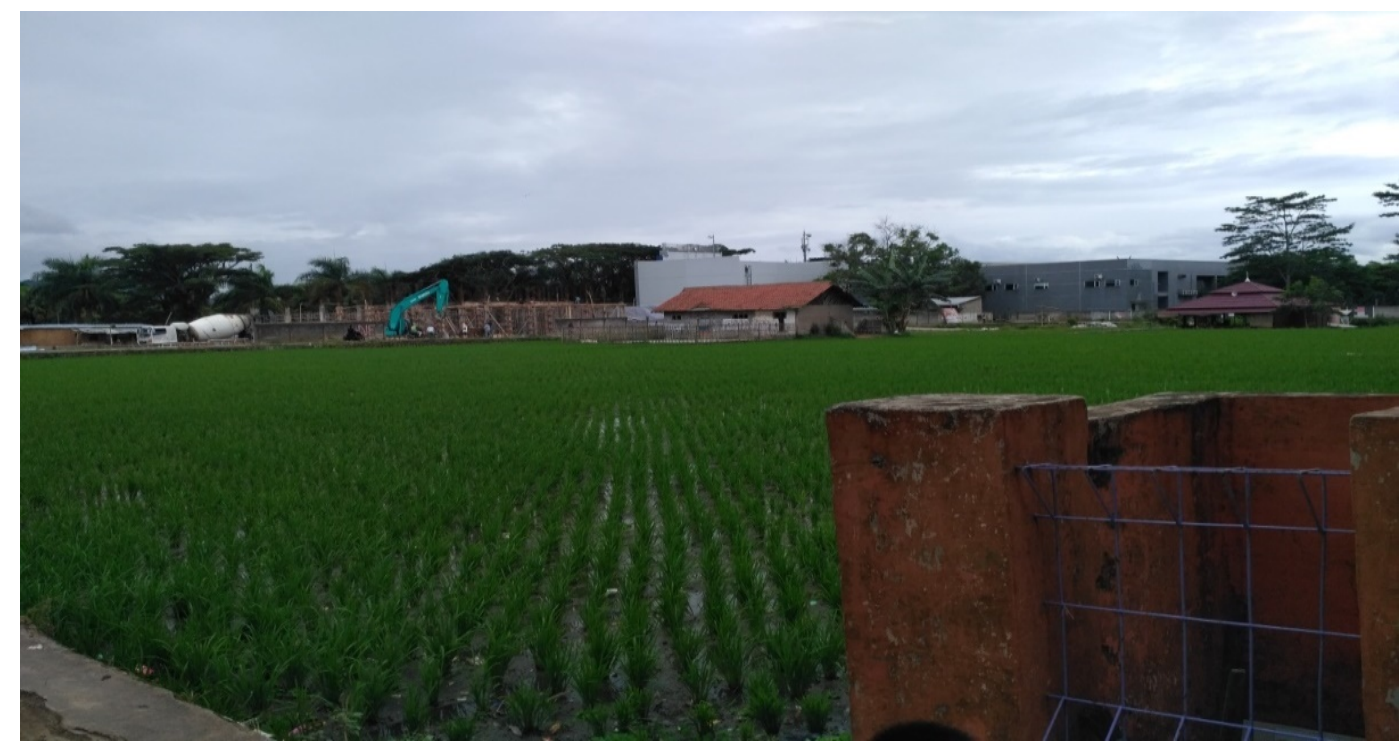

Gambar 1. Pembangunan Gedung yang Sedang Berlangsung di Area Kota Baru Parahyangan Sumber: Dokumentasi Peneliti, 2018.

Pembelian lahan juga dilakukan secara bertahap oleh pihak Kota Baru Parahyangan. Pembelian lahan-lahan tersebut sudah dimulai sejak lama, yakni semenjak tahun 80-an. Proses jual beli lahan yang terjadi juga melibatkan campur tangan pihak lain, dalam hal ini adalah calo. 
Calo-calo tersebut biasanya mendatangi rumah-rumah warga dan menawarkan pembelian lahan berdasarkan harga tertentu.

Berdasarkan informasi yang dihimpun, masyarakat yang memiliki lahan di RW 14 dan 15 menjual lahannya ke pihak Kota Baru Parahyangan dipengaruhi oleh beberapa faktor, diantaranya adalah sebagai berikut:

1. Faktor harga.

2. Faktor ekonomi.

3. Intimidasi dari oknum-oknum tertentu. Intimidasi dilakukan kepada warga masyarakat yang tidak mau menjual lahan dan bangunan rumah mereka ke pihak Kota Baru Parahyangan. Masyarakat tersebut tidak mau menjual lahan dan bangunan rumah mereka lantaran tidak ingin direlokasi. Salah satu bentuk intimidasi yang dilakukan oleh oknum tersebut adalah menggedor-gedor pintu rumah warga pada malam hari.

4. Masyarakat tidak diberikan akses ke lahan pertanian/perkebunan mereka oleh pihak Kota Baru Parahyangan apabila lahan-lahan di sekelilingnya telah dijual oleh masyarakat setempat dan telah menjadi milik pihak Kota Baru Parahyangan. Tidak tersedianya akses baik jalan, irigasi dan sebagainya membuat masyarakat yang awalnya tidak mau menjual lahan mereka terpaksa harus menjual lahan tersebut ke pihak Kota Baru Parahyangan.

\section{Mata Pencaharian Masyarakat Paska Pembangunan Perumahan Kota Baru Parahyangan}

Pasca pembangunan perumahan kota Baru Parahyangan banyak perubahan yang terjadi pada masyarakat Dusun 3, RW.14 dan RW.15. Perubahan tersebut salah satunya adalah aspek mata pencaharian masyarakatnya. Alih fungsi lahan yang terjadi di RW. 14 dan RW. 15, memaksa masyarakat untuk beralih profesi dari petani penggarap ke sektor pekerjaan lain di luar sektor pertanian. Sebagai petani penggarap, lahan tentu merupakan aset yang sangat penting bagi masyarakat. Ketika pembangunan Kota Baru parahnyangan dilakukan banyak lahan-lahan produktif dengan tanaman padi di RW. 14 dan RW. 15 dialihfungsikan untuk pembangunan perumahan. Hal tersebut berarti, dengan adanya alih fungsi lahan pertanian tersebut membuat para petani penggarap kehilangan aset mereka, kahilangan aset berupa lahan pertanian sama halnya dengan kehilangan pekerjaan bagi para petani, mengingat pentingnya lahan sebagai wadah bagi para petani untuk mengembangkan berbagai macam bentuk produk pertaniannya. Kehilangan pekerjaan yang diakibatkan oleh alih fungsi lahan tentu memaksa masyarakat yang awalnya bekerja sebagai petani penggarap menyesuaikan diri dengan kondisi baru yang 
diakibatkan oleh perubahan yang terjadi. Menyesuaikan diri dengan kondisi baru tersebut tentu menggunakan dan memanfaatkan sumber daya yang ada untuk bertahan hidup. Seperti yang diungkapkan oleh Ellis \& Allison (2004, dikutip Hariadi 2017:15-16), dalam melakukan kegiatan (pekerjaan) dalam memenuhi kebutuhannya, manusia memanfaatkan sumber daya yang tersedia, di mana sumber daya tersebut terbagi kedalam beberapa tipe, yakni modal manusia, modal fisik, modal finansial, modal alam dan modal sosial. Dengan menggunakan dan memanfaatkan sumber daya yang tersedia masyarakat mampu untuk beradaptasi dengan kondisi yang baru, yakni menyesuaikan pekerjaan-pekerjaan yang akan mereka lakoni dengan situasi dan kondisi yang ada, sesuai dengan kebutuhan pekerjaan tersebut di dalam masyarakat dan kapasitas masyarakat tersebut untuk melakoni pekerjaan tersebut.

Dengan melakukan adaptasi dengan kondisi-kondisi baru yang diakibatkan oleh perubahan yang terjadi masyarakat mampu untuk mengembangkan potensi-potensi yang ada sebagai upaya untuk bertahan hidup. Disamping kehilangan pekerjaan akibat alih fungsi lahan, pembangunan perumahan Kota Baru Parahnyangan juga mendatangkan sumber-sumber lapangan pekerjaan baru bagi masyarakat di sekitarnya. Oleh karenanya, masyarakat beradaptasi dengan menggunakan dan memanfaatkan sumber daya tersebut sebagai upaya untuk mempertahankan kehidupan mereka.

Pasca pembangunan perumahan Kota Baru Parahyangan mayoritas masyarakat Dusun 3, RW.14 dan RW. 15 melakoni pekerjaan di kompleks perumahan Kota Baru Parahyangan sebagai pekerja bangunan, pekerja taman (petugas kebersihan), dan pembantu rumah tangga. Selain itu, sebagian besar masyarakat juga menggantungkan hidup sebagai buruh pabrik. Dengan melakoni pekerjaan tersebut masyarakat mampu untuk memenuhi kebutuhannya sehari-hari. Walaupun mampu untuk memenuhi kebutuhan sehari-hari, masyarakat belum memiliki kemampuan untuk menabung maupun berinvestasi. Hal ini dikarenakan mayoritas masyarakat hanya memiliki upah yang pas-pasan atau hanya mampu memenuhi kebutuhan sehari-hari saja. Masyarakat dalam melakoni pekerjaan tersebut dipengaruhi oleh beberapa faktor, di antaranya adalah tidak tersedianya lapangan pekerjaan lain, pendidikan yang rendah dan tidak adanya keahlian.

Apabila dibandingkan dengan kondisi sebelum pembangunan Kota Baru Parahyangan, mata pencaharian masyarakat pasca pembangunan Kota Baru Parahyangan dapat dikatakan mengalami perubahan secara signifikan. Perubahan mata pencaharian tersebut terjadi pada sektor pertanian ke sektor non pertanian. Mata pencaharian masyarakat pasca pembangunan perumahan Kota Baru Parahyangan dapat dikatakan beragam apabila dibandingkan dengan mata pencaharian masyarakat sebelum pembangunan perumahan Kota Baru Parahyangan, 
dimana mayoritas masyarakatnya hanya melakoni pekerjaan sebagai petani penggarap. Masyarakat menggantungkan hidup sebagai petani penggarap sebelum pembangunan perumahan Kota Baru Parahyangan dengan mengelola lahan pertanian milik orang lain dipengaruhi oleh beberapa faktor, di antaranya adalah tidak adanya ketersediaan peluang pekerjaan lain, pendidikan yang rendah dan adanya kebiasaan turun-temurun, oleh karenanya, masyarakat hanya menetap di rumah dengan bercocok tanam walaupun pada lahan milik orang lain. Selain itu, juga terdapat faktor lain yakni ketersediaan sumber daya alam di antaranya adalah lahan yang luas, kondisi irigasi yang baik, dan hasil komoditas panen yang bagus.

Sebelum pembangunan perumahan Kota Baru Parahyangan, pendapatan masyarakat dengan melakoni pekerjaan sebagai petani penggarap dapat mencukupi kebutuhan sehari-hari karena masyarakat tidak menjual hasil lahan garapan mereka, akan tetapi hanya untuk konsumsi pribadi saja. Adapun hasil panen yang dijual hanya untuk modal menggarap ulang sawah yang telah dipanen sebelumnya. Dengan memanfaatkan hasil panen tersebut masyarakat dapat mencukupi kebutuhan untuk panen berikutnya. Tidak jauh berbeda dengan kondisi pasca pembangunan perumahan Kota Baru Parahyangan, pada saat sebelum pembangunan perumahan Kota Baru Parahyangan masyarakat juga belum memiliki kemampuan untuk memiliki tabungan maupun berinvestasi.

\section{Mobilitas Sosial Masyarakat Pasca Pembangunan Perumahan Kota Baru Parahyangan}

Secara sosiologis, perubahan mata pencaharian yang terjadi pada masyarakat Dusun 3, RW. 14 dan RW. 15 Desa Kertajaya pasca pembangunan Kota Baru Parahyangan berimplikasi terhadap mobilitas sosial masyarakatnya. Menurut Horton dan Hunt (1984:36), mobilitas sosial adalah suatu keinginan yang ingin dicapai, baik status atau penghasilan yang lebih tinggi dari orang tua seseorang. Gagal maupun berhasilnya seseorang tersebut dalam mencapai tujuan mereka tersebut itulah yang dinamakan dengan mobilitas sosial. Menurut Sorokin (1928, dikutip dari Soekanto 2007:220) mobilitas sosial secara prinsipil dibedakan dibedakan menjadi dua macam, yakni mobilitas sosial horizontal dan mobilitas sosial vertikal.

Berdasarkan pemaparan yang telah dijelaskan pada pembahasan sebelumnya, bahwa terdapat perubahan mata pencaharian pada masyarakat Dusun 3, RW. 14 dan RW. 15, Desa Kertajaya dari yang awalnya mayoritas masyarakat bekerja sebagai petani penggarap atau buruh tani sebelum pembangunan perumahan Kota Baru Parahyangan, mengalami perubahan mata pencaharian pada saat pasca pembangunan perumahan Kota Baru Parahyangan dengan mayoritas masyarakat bekerja sebagai pekerja bangunan, pekerja taman (petugas kebersihan), pembantu rumah tangga dan buruh pabrik. Mobilitas sosial yang terjadi pada masyarakat Dusun 3, RW. 14 dan RW. 15, Desa Kertajaya pada saat pasca pembangunan perumahan Kota 
Baru Parahyangan dapat dikatakan berada dalam posisi mobilitas sosial horizontal apabila dilihat dari sudut pandang status pekerjaan tersebut di dalam masyarakat. Di mana status pekerjaan masyarakat pada saat sebelum dan pasca pembangunan Kota Baru Parahyangan sama-sama berada pada posisi yang setara atau sejajar, yakni masyarakat menggeluti pekerjaan sebagai pekerja kasar atau buruh. Dalam studi mengenai pekerjaan, para ahli sosiologi telah menguraikan mengenai struktur pekerjaan.

Struktur pekerjaan dipandang sebagai "pola dalam masyarakat yang diciptakan oleh distribusi tenaga kerja di berbagai jenis pekerjaan atau pekerjaan yang ada" (Watson 2003:174). Menurut Watson, pola yang dimaksudkan tersebut dapat dicari, contohnya dengan faktor pembeda hirarkis (berjenjang) dan horizontal (sejajar) dalam struktur pekerjaan tersebut. Pada pembahasan ini, tidak akan secara khusus membahas mengenai diferensiasi horizontal dalam pembagian tenaga kerja, akan tetapi akan membahas mengenai hirarki pembagian tenaga kerja tersebut di dalam masyarakat. Para ahli sosiologi seringkali mencoba untuk membagi dan mengelompokkan tenaga kerja berdasarkan kelas sosial ekonomi yang dimiliki guna memudahkan analisis, salah satunya adalah skema posisi kelas yang digunakan dalam penelitian tentang mobilitas kelas di Inggris (Goldthorpe dkk, 1980, dikutip dari Watson 2003:175). Kategori yang digunakan adalah diferensiasi fungsi pekerjaan dan status pekerjaan tersebut di masyarakat. Pengelompokkan kelas pekerjaan tersebut adalah sebagai berikut:

1. Kelas I : profesional kelas atas, administrator, manajer, dan pebisnis.

2. Kelas II : profesional kelas rendah, administrator dan manajer; teknisi dan supervisor yang lebih tinggi dari karyawan manual.

3. Kelas III : pekerja non-manual rutin, sebagian besar ulama; tenaga penjualan dan pekerja sejenis serta file service workers.

4. Kelas IV : small proprietors; pengrajin mandiri dan pekerja mandiri non profesional lainnya.

5. Kelas $\mathrm{V} \quad$ : teknisi kelas bawah dan pengawas pekerja manual.

6. Kelas VI : pekerja upahan manual yang terampil.

7. Kelas VII : pekerja upahan manual yang terampil; pekerja semi dan tidak terampil.

Bersadasarkan pembagian kelas pekerjaan yang telah diuraikan tersebut dapat diambil kesimpulan bagaimana mobilitas sosial yang terjadi pada masyarakat Dusun 3, RW. 14 dan RW. 15, Desa Kertajaya sebagai implikasi dari perubahan mata pencaharian yang terjadi pada saat sebelum dan pasca pembangunan Kota Baru Parahyangan. Pada saat sebelum pembangunan Kota Baru Parahyangan, dengan menggeluti pekerjaan sebagai buruh tani, 
masyarakat RW 14 dan 15 Desa kertajaya dapat diklasifikasikan berada pada kelas paling bawah, yakni kelas VII sebagai pekerja tidak terampil. Tidak jauh berbeda dengan kondisi pasca pembangunan Kota Baru Parahyangan, pekerjaan mayoritas masyarakat RW 14 dan 15 juga diklasifikasikan pada kelas VII, sebagai pekerja tidak terampil dengan menggeluti pekerjaan sebagai pekerja banguanan, pekerja taman (petugas kebersihan), pembantu rumah tangga dan buruh pabrik. Oleh karena itu, dapat disimpulkan bahwa mobilitas sosial yang terjadi pada masyarakat Desa Kertajaya, Dusun 3, RW. 14 dan RW. 15berada pada posisi mobilitas sosial horizontal. Masyarakat melakukan perpindahan dalam status dan kelas sosial yang sama atau sejajar.

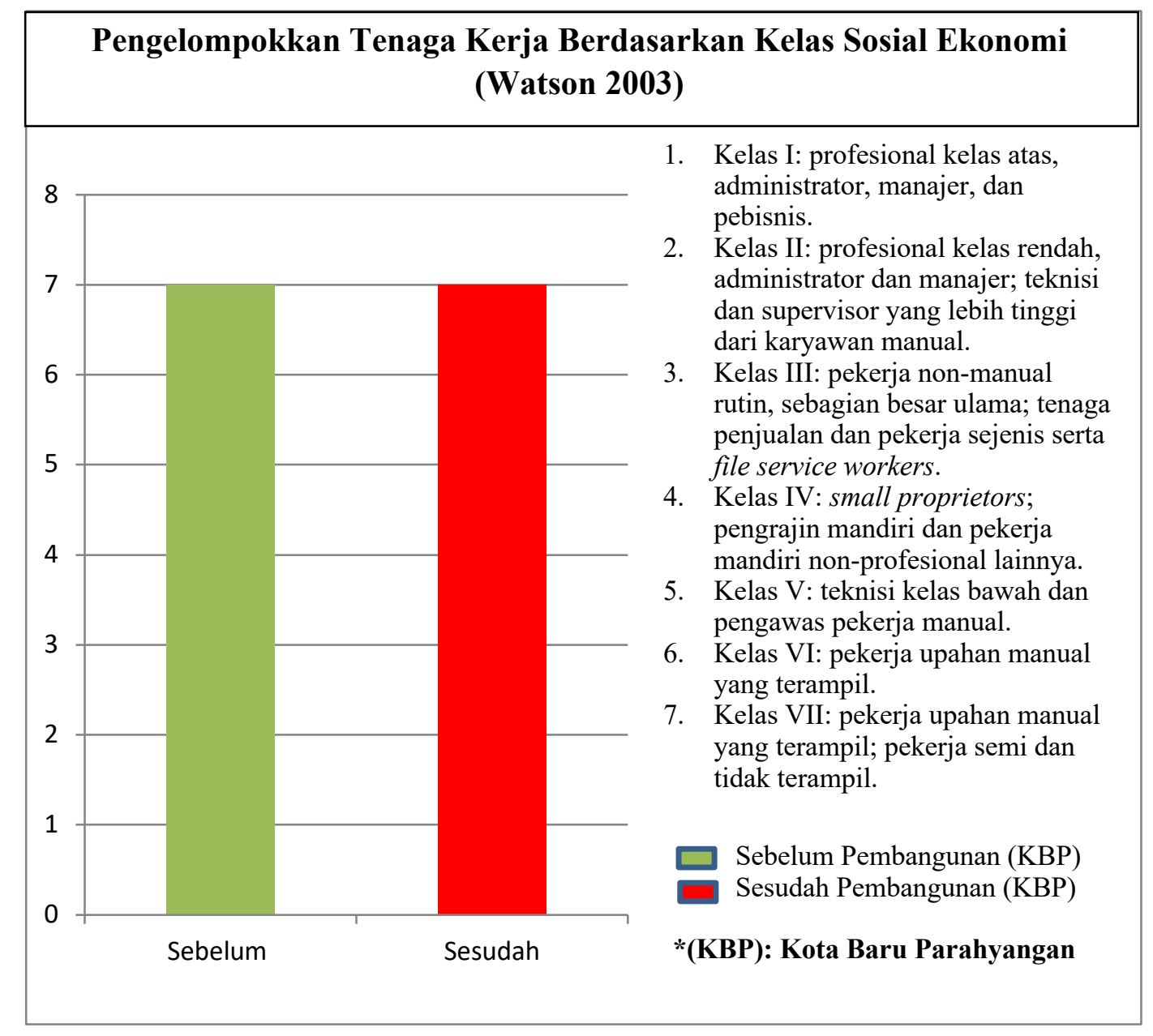

Gambar 2. Diagram Proses Mobilitas Sosial yang Terjadi pada Masyarakat Dusun 3 RW 14 dan 15 Desa Kertajaya (Pengelompokan Tenaga Kerja Berdasarkan Kelas Sosial Ekonomi (Watson, 2003))

Sumber: Data Olahan Peneliti, 2018.

Pengelompokan kelas berdasarkan pembagian pekerjaan juga telah dirumuskan oleh Badan Pusat Statistik (BPS) yang tersusun dalam Klasifikasi Baku Jenis Pekerjaan Indonesia (2002). 
Dalam klasifikasi ini terdapat sepuluh golongan pokok pekerjaan, diantaranya adalaha sebagai berikut:

0. Anggota Tentara Nasional Indonesia (TNI) dan kepolisian negara republik Indonesia.

1. Pejabat legislatif, pejabat tinggi, dan manajer.

2. Tenaga profesional.

3. Teknisi dan asisten tenaga profesional.

4. Tenaga tata usaha.

5. Tenaga usaha jasa dan tenaga usaha penjualan di toko dan pasar.

6. Tenaga usaha pertanian dan peternakan.

7. Tenaga pegolahan dan kerajinan serta yang berhubungan dengan itu.

8. Operator dan perakit mesin.

9. Pekerja kasar, tenaga kebersihan, dan tenaga yang berhubungan dengan itu.

Berdasarkan pemaparan tersebut, dapat dilihat bahwa pekerjaan mayoritas masyarakat RW 14 dan 15 Desa Kertajaya pada saat sebelum dan pasca pembangunan Kota Baru Parahyangan sama-sama dikategorikan pada golongan pokok sembilan, yakni pekerja kasar, tenaga kebersihan, dan tenaga lainnya yang berhubungan dengan itu. Yakni, sebelum pembangunan Kota Baru Parahyangan mayoritas masyarakat melakoni pekerjaan sebagai petani penggarap atau buruh tani yang mengolah lahan milik orang lain dengan sistem bagi hasil. Sedangkan, pasca pembangunan Kota Baru Parahyangan mayoritas masyarakat melakoni pekerjaan sebagai pekerja bangunan, pekerja taman (petugas kebersihan), pembantu rumah tangga dan buruh pabrik. 


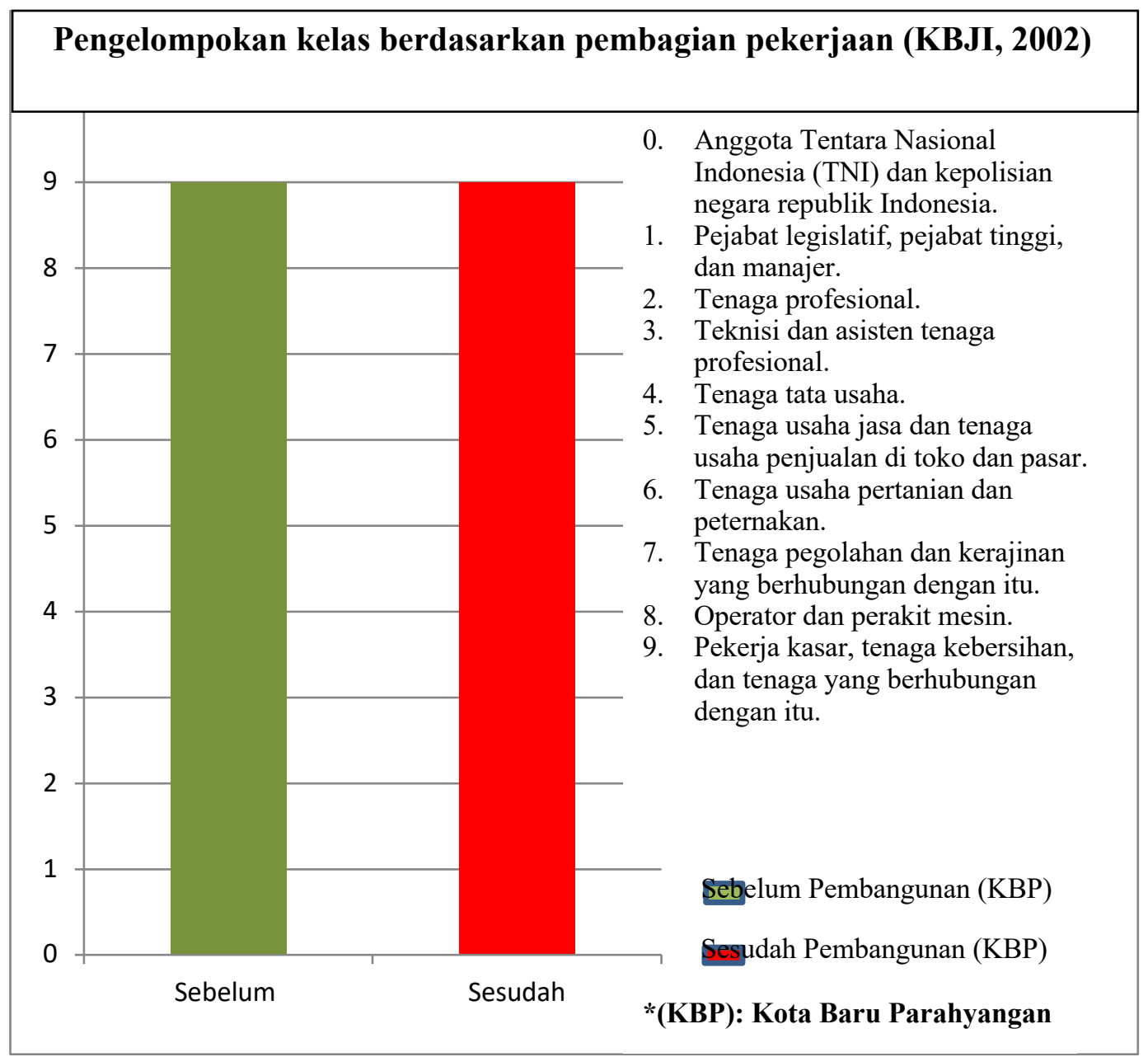

Gambar 3. Diagram Proses Mobilitas Sosial yang Terjadi pada Masyarakat Dusun 3 RW.14 dan RW.15 Desa Kertajaya (Pengelompokan kelas berdasarkan pembagian pekerjaan (KBJI, 2002))

Sumber: Data Olahan Peneliti, 2018.

Berdasarkan pemaparan tersebut, tidak jauh berbeda dengan unit analisis kelas sosial berdasarkan pembagian pekerjaan (Watson 2003) seperti yang telah diuraikan pada pembahasan sebelumnya, dapat disimpulkan bahwa mobilitas sosial yang terjadi pada masyarakat Dusun 3 RW 14 dan 15 Desa Kertajaya pada saat pasca pembangunan Kota Baru Parahyangan adalah mobilitas sosial horizontal. Yakni, masyarakat melakukan perpindahan dari status pekerjaan mereka pada posisi yang sejajar atau setara. Masyarakat RW. 14 dan RW. 15 pada saat sebelum dan pasca pembangunan Kota Baru Parahyangan sama-sama menggeluti status pekerjaan yang sama, yakni sebagai buruh atau pekerja kasar, akan tetapi pada sektor yang berbeda. Di mana sebelum pembangunan Kota baru Parahyangan masyarakat melakoni pekerjaan pada sektor pertanian, yakni sebagai buruh tani. Akan tetapi, pasca pembangunan Kota Baru parahyangan, mayoritas masyarakat melakoni pekerjaan sebagai buruh di luar sektor 
pertanian, baik sebagai pekerja bangunan, pekerja taman (petugas kebersihan), dan pembantu rumah tangga, serta di antara masyarakat juga melakoni pekerjaan sebagai buruh pabrik.

\section{SIMPULAN}

Mobilitas sosial yang terjadi pada masyarakat Dusun 3, RW.14 dan RW.15, Desa Kertajaya Kecamatan Padalarang Kabupaten Bandung Barat pasca pembangunan perumahan Kota Baru Parahyangan adalah mobilitas sosial horizontal, dimana masyarakat melakukan perpindahan atau pergerakan dari status pekerjaan mereka pada posisi yang sejajar atau setara. Mobilitas sosial yang terjadi merupakan implikasi dari perubahan mata pencaharian yang terjadi pada saat sebelum dan pasca pembangunan perumahan Kota Baru Parahyangan. Di mana sebelum pembangunan perumahan Kota Baru Parahyangan mayoritas masyarakat melakoni pekerjaan sebagai petani penggarap, sedangkan pasca pembangunan perumahan Kota Baru Parahyangan mayoritas masyarakat melakoni pekerjaan sebagai pekerja bangunan, pekerja taman (petugas kebersihan), pembantu rumah tangga dan buruh pabrik. Baik sebelum maupun pasca pembangunan perumahan Kota Baru Parahyangan, status pekerjaan masyarakat sama-sama diklasifikasikan sebagai buruh atau pekerja kasar, akan tetapi berada pada sektor yang berbeda. Dimana pasca pembangunan perumahan Kota Baru Parahyangan masyarakat melakoni pekrerjaan di sektor non pertanian, sedangkan sebelum pembangunan perumahan Kota Baru Parahyangan masyarakat melakoni pekerjaan di sektor pertanian.

\section{DAFTAR PUSTAKA}

\section{Buku}

Basrowi. 2005. Pengantar Sosiologi. Bogor: Ghalia Indonesia.

Evers, Hans Dieter. 1986. Sosiologi Perkotaan: Urbanisasi dan Sengketa Tanah di Indonesia dan Malaysia. Jakarta: LP3ES.

Horton, Paul B. \& Chester L. H. 1984. Sosiologi Jilid 2. Jakarta: Penerbit Erlangga.

Soekanto, Soerjono. 2007. Sosiologi Suatu Pengantar. Jakarta: PT. Raja Grafindo Persada.

Watson, Tony J. 2003. Sociology, Work and Industry. Inggris: Taylor \& Francis e-Library.

\section{Skripsi}

Hariadi, Nanda. 2017. "Perubahan Mata Pencaharian di Desa Hegarmanah Kecamatan Jatinangor Kabupaten Sumedang.” Skripsi, Sumedang: Program Studi Sosiologi Fakultas Ilmu Sosial dan Ilmu Politik Universitas Padjadjaran.

Wirawan, Nurul Q .2016. "Mobilitas Sosial Pasca Alih Fungsi Lahan di Desa Bojong Haleuang Kecamatan Saguling Kabupaten Bandung Barat." Skripsi, Sumedang: Program Studi Sosiologi Fakultas Ilmu Sosial dan Ilmu Politik Universitas Padjadjaran.

\section{Jurnal}

Kemong, Bonefasius (t.t.) Sistem Mata Pencabarian Hidup Nelayan Tradisional Sukubangsa Kamoro di Desa Tipuka Kecamatan Mapurujaya Kabupaten Mimika Propinsi Papua. [internet], pp. 1 19. Diunduh dari : <https://media.neliti.com/media/publications/949-ID-sistem-mata- 
pencaharian-hidup-nelayan-tradisional-sukubangsa-kamoro-di-desa-tipu.pdf $>$ [diakses pada 15 November 2017].

\section{Dokumen Elektronik}

Data Jumlah dan Laju Pertumbuhan Penduduk Kota Bandung < https://bandungkota.bps.go.id/> [diakses pada 5 Oktober 2017].

KBJI 2002: Klasifikasi Baku Jenis Pekerjaan Indonesia < https://www.google.co.id/url?sa=t\&source=web\&rct=j\&url=https:// sirusa.bps.go.id/ webadmin/doc/KBJI2002.pdf\&ved=2ahUKEwjd56TUwfXbAhUSXCsKHcfuCeIQFj AAegQIABAB\&usg=AOvVaw0qo4gjZ6KNhuTTs-q5fkin> [diakses pada 28 Juni 2018]. 